\title{
The effect of using WhatsApp in online learning setting on Indonesian EFL students' writing apprehension and the relation with their writing achievement
}

\author{
Arum Habibah $^{1}$, Ari Nurweni ${ }^{2}$, Rafista Deviyanti ${ }^{3}$ \\ FKIP Universitas Lampung, Jl. Prof. Dr. Sumantri Brojonegoro, Rajabasa, Bandarlampung ${ }^{1,2,3}$ \\ ${ }^{1}$ Correspondence: arumhabibah18@gmail.com
}

\begin{abstract}
The primary goals of this research are to investigate the students' writing apprehension level after being taught through WhatsApp in online learning setting and to find out the correlation between writing apprehension and writing achievement. This study was carried out quantitatively and involved one class of grade $X$ which consisted of thirty-five students. The data was collected through English Writing Test and Writing Apprehension Test, a questionnaire that was developed by Daly and Miller (1975). To test the hypotheses, paired sample t-test and Pearson correlation analysis were applied. The finding of paired sample t-test revealed that there was a significant reduction in the students' writing apprehension level after the implementation of WhatsApp in online writing classes. Meanwhile, for the correlational analysis, it was done three times to obtain more specific results; the correlation of the data before the treatment, the correlation of the data after the treatment, and the correlation of gain scores of the data. The results showed respectively that two correlational analyses had very high correlation and the last one had an average correlation. Furthermore, all findings showed significant negative correlation; meaning that there was a significant inverse relationship between writing apprehension and writing achievement. This implied that the lower the level of writing apprehension is, the higher the score of writing achievement would be. In conclusion, the implementation of WhatsApp in online writing class is effective to improve students' writing achievement and effective to reduce students' writing apprehension in Indonesian EFL students.
\end{abstract}

Keywords: WhatsApp, online learning, writing apprehension, writing achievement.

\section{INTRODUCTION}

Among four English skills (listening, speaking, reading, and writing), writing is commonly known as the most difficult and the least liked skill although it plays a crucial role in language production. English writing is a skill that needs to be mastered by EFL learners in order to be able to produce a written composition in different specific objectives and emphasis (Sanu, 2016). Theoretically, writing is a way to produce language and express ideas, feelings, and opinions (Harmer, 2004). However, according to Ariyanti (2016), students still have difficulties in mastering writing even though it is an essential skill to acquire by students. It apparently happens since writing is complicated activity yet believed as the most complex and difficult language skill to acquire both in the writer's native language and foreign language (Richards and Renandya, 2002; Alwasilah, 2004; Yuliana, Imperiani, and Kurniawan, 2016). Writing in a foreign language is even more challenging because it deals with the target language's rules which include grammar and rules usage, vocabulary, and discourse (Hung, 2006 in Yuliani, Imperiani, and Kurniawan, 2016). As a result, due to the complexity of writing and its various requirements, EFL learners usually have negative perceptions towards writing which is generally known as writing apprehension (Challob, Bakar and Latif, 2016). 
According to Huwari and Al Shboul (2016), students feel uneasy when teachers ask them to compose a text. They are mostly unconfident of their capability to put their ideas and facts into papers since they are afraid that their ideas cannot be written in grammatically correct. On the other hand, learners' abilities, ideas and plans, time constraints, teacher's comments, and learner's fear are probably some causes that heighten their apprehension level (Al_Sawalha, et al., 2012 ).

Talking about apprehension, Horwitz, Horwitz, and Cope (1986) propose that apprehension is commonly known as a mental block against learning a foreign language. Apprehension apparently evokes English learners feeling difficult to comprehend materials and avoid taking writing classes (Cheng, 2002). Then writing apprehension can be assumed as a situation in which associated with one's tendencies to avoid writing activity. Simply to say, writing apprehension is a psychological situation faced by an individual that dealt with writing task and affects the writing process and performance (Sundari and Febriyanti, 2017).Writing apprehension can be reduced in many ways, teachers should modify their teaching instruction to minimize students' apprehension in writing. Furthermore, the teacher should apply proper teaching methods or techniques for students in the class, create a good atmosphere for students to study, and choose the proper media to enhance students' motivation to study.

The use of technology seems to be effective to cope with this issue since we live in an era where sophisticated technology exists and is still continuously developed. It is in line with the study of Gilakjani (2013) who proposes that the use of technologies has great potential to change the existing language teaching methods. Still, besides the use of technology, the learning model should be precise and not monotonous in the class only. The learning model should also be able to facilitate and support students in learning a language especially writing. As a result, in this study, the implementation of online learning seems to be potentially effective to lower students' apprehension levels in writing. It is believed that providing students with self-paced online learning opportunities will enhance students' learning performance in the language (Krasnovaand Ananjev in Challob, et. al., 2016). Furthermore, online learning has many advantages such as improving the effectiveness and efficiency of learning by exploring students' abilities through online media and building communication with students through online media. (Clyde and Delohery, 2005 cited by Pranoto, Suciati, and Sunarno, 2014).

In this study, the researcher considers WhatsApp as a good media to use in implementing online learning; the reason that WhatsApp is a tool the students use on a daily basis, they know how to use it (Han and Keskin, 2016). Moreover, WhatsApp happens to be a popular messenger in Indonesia that most people use it most of the time, also has already been proved by plenty of researchers that this medium is effective to enhance learning activity. In the study of Rambe and Bere (2013) and Rambe and Chipunza (2013), they propose that WhatsApp has become a shared platform that enhances accessibility, encourages cooperation, and intensifies motivation to take an active part in academic assignments. In the case of writing apprehension, Mhandeni, Mwakapina, and Nyinondi (2016) state that students are always worried about making mistakes as they learn, but WhatsApp makes them feel relaxed among friends. In that case, they are much likely to participate and learn more, especially it does not need face to face interactions. 
Nevertheless, this study also seeks the correlation between students' writing apprehension and writing achievement. This idea has been brought up since the term writing apprehension apparently has a tight bond with writing performance and achievement. These two terms are highly associated because students' writing apprehension is mirrored in their written products. Moreover, it is also supported by plenty of studies investigating the relationship between students' writing apprehension and writing achievement. As seen in the study of Fowler and Ross (1982), and Powell (1984) as cited in Erkan and Saban (2011), they report that highly apprehensive students were more likely to receive low grades in composition classes. Then, there are Masny and Foxall (1992) as cited in Kim (2006) who reveal that high achieving writers were less apprehensive. Further, Erkan and Saban (2011) show that writing apprehension directly affects writing performance. In sum, based on the various studies explained before, it is known that those two variables are correlated with each other; writing apprehension and writing achievement have negative correlation. The following specific research questions guided the study:

1. Can the implementation of online learning using WhatsApp significantly reduce students' writing apprehension level?

2. Is there any significant correlation between writing apprehension level and writing achievement?

\section{METHOD}

\section{Participant}

The participants of this study were 35 first grade students of SMA Negeri 13 Bandar Lampung which were taken randomly.

\section{Instrument}

Two instruments were applied in this study: writing test and an adapted writing apprehension questionnaire namely Daly Miller Writing Apprehension Test. Writing apprehension questionnaire (DM-WAT) and writing tests were distributed twice; in the beginning before the treatments and the last meeting after the treatrments.

\section{Data Analysis}

The questionnaire which is Writing Apprehension Test in the study had four possible responses ranged from 1 to 4 for each item. The scoring gives a point ranged from 26 to 130 in total and a higher score indicated a higher degree of WA in English writing. Meanwhile, the results of writing test are scored by the analytical scoring system by Jacob (1981). After being scored, the data is analyzed using Paired Sample T-Test and Pearson Correlation through SPSS.

\section{RESULT AND DISCUSSION}

\section{Results}

The results were based on the responses to the distributed questionnaire and scores of writing test. The data was analyzed and interpreted using SPSS in order to provide answers for the research questions. The results of pre-administration WAT shows $34.3 \%$ of the respondents or 12 students were experiencing low writing apprehension level. Meanwhile, the rest of the students or $65.7 \%$ of the respondents suffered high writing apprehension. It can clearly be 
concluded that the majority of students' initial writing apprehension level was high. However, it was found out that the treatments contributed to reducing the level. The results in the postadministration WAT revealed that there were 29 students or $82.9 \%$ of students experienced low writing apprehension level. It means the other 17 students who were initially experiencing high writing apprehension level reduced to the low writing apprehension level after the treatments.

On the other hand, the mean of pre-test writing was 73.57 while the mean of post-test writing was 77.70. It means that the scores increased by 4.13 points. Based on the findings, it can be said that the students have done a good job in writing since the start. Still, the treatments gave some impacts to increase their scores.

This study had two hypotheses to be measured. The first one was to find out if there is any significant reduction in students' writing apprehension using Paired Sample T-Test, and the second one was to find out the correlation between students' writing apprehension level and writing achievement using Pearson Correlation in SPSS.

Below is the result of the first hyphothesis:

Table 1. Students' Writing Apprehension Level Reduction

\begin{tabular}{|c|c|c|c|c|c|c|c|c|c|}
\hline \multicolumn{10}{|c|}{ Paired Sample T-Test } \\
\hline & & \multicolumn{5}{|c|}{ Paired Differences } & \multirow[b]{3}{*}{$\mathrm{T}$} & \multirow{3}{*}{\multicolumn{2}{|c|}{$\begin{array}{r}\text { Sig. } \\
(2- \\
\text { df tailed } \\
\end{array}$}} \\
\hline & & \multirow[b]{2}{*}{ Mean } & \multirow{2}{*}{$\begin{array}{c}\text { Std. } \\
\text { Deviation }\end{array}$} & \multirow{2}{*}{$\begin{array}{l}\text { Std. } \\
\text { Error } \\
\text { Mean }\end{array}$} & \multicolumn{2}{|c|}{$\begin{array}{c}95 \% \\
\text { Confidence } \\
\text { Interval of the } \\
\text { Difference }\end{array}$} & & & \\
\hline & & & & & Lower & Upper & & & \\
\hline Pair 1 & $\begin{array}{l}\text { WAT pre-administration - } \\
\text { WAT post-administration }\end{array}$ & 7.143 & 2.724 & .460 & 6.207 & 8.079 & 15.513 & 34 & .000 \\
\hline
\end{tabular}

The table above shows that the result of the analysis of two-tailed significance was 0.000 which is lower than $0.05(0.00<0.05)$. It indicated that the alternate hypothesis $\left(\mathrm{H}_{1}\right)$ was accepted, meaning that there is a significant reduction in the students' apprehension level after the treatments. Thus, it could be concluded that the implementation of teaching writing using WhatsApp in online-based learning can significantly reduce the students' writing apprehension level.

The correlational analysis was done to measure the second hypothesis. Instead of one-time analysis, this test was done three times to obtain more specific results.

Table 2.

Correlation between Writing Apprehension and Writing Achievement before the Treatment

\begin{tabular}{llll}
\hline & & Pre-test & $\begin{array}{c}\text { Pre-administration } \\
\text { WAT }\end{array}$ \\
\hline \multirow{3}{*}{ Pre-test } & Pearson Correlation & 1 & $-.804^{* * *}$ \\
& Sig. (2-tailed) & & .000 \\
$\mathrm{~N}$ & 35 & 35
\end{tabular}




\begin{tabular}{llll} 
& Pearson Correlation & $-.804^{* *}$ & 1 \\
Pre-administration WAT & Sig. (2-tailed) & .000 & \\
& $\mathrm{~N}$ & 35 & 35 \\
\hline
\end{tabular}

**. Correlation is significant at the 0.01 level (2-tailed).

The produced output Table 2 showed the Pearson Correlation coefficient value of, $r=-0.804$ and $\mathrm{p}=0.000$ which is smaller than the significant level $0.05(\mathrm{p}<0.05)$. Referring to the table above, the value of $r$ was negative. Then, it can be summed up that there was a significant very high or very strong negative correlation between students' writing apprehension level and writing achievement before the treatments.

Table 3.

Correlations between Writing Apprehension and Writing Achievement after the Treatment

\begin{tabular}{llll}
\hline & & Post test & \multicolumn{1}{c}{$\begin{array}{c}\text { Post- } \\
\text { administration } \\
\text { WAT }\end{array}$} \\
\hline \multirow{3}{*}{ Post-test } & Pearson Correlation & 1 & $-.876^{* * *}$ \\
& Sig. (2-tailed) & & .000 \\
& N & 35 & 35 \\
Post-administration WAT & Pearson Correlation & $-.876^{* *}$ & 1 \\
& Sig. (2-tailed) & .000 & \\
& N & 35 & 35 \\
\hline **. Correlation is significant at the 0.01 level (2-tailed). & &
\end{tabular}

The produced output Table 3 above revealed the Pearson Correlation value of, $r=-0.876$ and $\mathrm{p}=0.000$ which is less than the significant level $0.05(\mathrm{p}<0.05)$. This analysis also showed negative correlation between those variables. In conclusion, there was a significant very high or very strong negative correlation between students' writing apprehension level and writing achievement after the treatments.

Table 4.

Correlations between Writing Apprehension and

Writing Achievement: Gain Score before and after the Treatment

\begin{tabular}{llll}
\hline & & gain writing test & \multicolumn{1}{c}{ gain questionnaire } \\
\hline \multirow{2}{*}{ gain writing test } & Pearson Correlation & 1 & $-.465^{* *}$ \\
& Sig. (2-tailed) & & .005 \\
& $\mathrm{~N}$ & 35 & 35 \\
& Pearson Correlation & $-.465^{* *}$ & 1 \\
gain questionnaire & Sig. (2-tailed) & .005 & \\
& $\mathrm{~N}$ & 35 & 35 \\
\hline **. Correlation is significant at the 0.01 level (2-tailed).
\end{tabular}

The finding of gain scores correlation can be seen in the table 4. After calculating the gain scores of pre- and post-test writing also pre- and post-administration questionnaire, the researcher analyzed the data using Pearson correlation. The results are $r=-0.465$ with $p=0.005$; negative (-) sign indicates negative correlation and the significant value (p) which is smaller than the significance level $0.05(\mathrm{p}<0.05)$ means that the correlation is significant. In conclusion, 
there was a significant average or moderate negative correlation between students' writing apprehension level and writing achievement in gain scores correlation analysis.

Based on the tables above, it can be concluded that there was significant inverse relationship between writing apprehension and writing achievement. This implied that the higher the level of writing apprehension is, the lower the score of writing achievement would be. Therefore, the alternate hypothesis was accepted.

\section{Discussion}

\section{Writing Apprehension Level of the Students}

Several studies in writing have found that there are many causes of writing apprehension. It was found that from several sources ranging from an individual's ability to write, have limited time to plan and to write, the fear of being assessed and judged by the teacher through the feedback, and the fear that the teacher would punish, scorn and embarrassment when their work is compared with others publicly (Daly, 1978 as cited in Erkan and Saban, 2011; Raisman, 1982; Pajares\& Johnson, 1994; as cited in Kim, 2006; Al-Sawalha, et al., 2012). Then, through the implementation of this study, the researcher was giving her best with the aim to cope all the causes mentioned before.

First, using WhatsApp in online writing class gave more time for the students to think of what to plan and what to write. Furthermore, since the students did not get face-to-face interaction with the teacher (researcher), the implementation of online learning offered them to express themselves more freely in WhatsApp group chat. Second, the researcher was working hard to deliver feedback in a good way, constructive feedback. The researcher tried her best to give them positive comments, appreciating their works, and gave them some advice to get better. All pieces of feedback were delivered in a friendly way to make them feel more comfortable, not feeling as being judged.

As a result, based on the research findings, it can be confirmed that the implementation of WhatsApp in online writing classes affected students' writing apprehension level positively. The quality of students' writings become way better and it directly affected their writing apprehension, meaning that the treatment successfully contributed to the reduction of students' writing apprehension level.

To the best of the researcher's knowledge, there was no prior study investigating the use of WhatsApp in reducing writing apprehension or writing anxiety. However, the present results were similar to the research findings of the studies investigating the use of WhatsApp in reducing students' apprehension in speaking skill conducted by Han and Keskin (2016) and Shamsi, Altaha, and Gilanlioglu (2019) as cited in Ali and Bin-Hady (2019), and similar to the findings of the study investigating the use of WhatsApp in reducing students' pronunciation anxiety by Aulia (2018). All the findings shared the same results that the implementation of WhatsApp can successfully decrease students' apprehension. Therefore, the researcher concluded that the activities implemented in WhatsApp can be helpful for foreign language students and can contribute to decreasing their apprehension in writing skill as well as in 
speaking skill. Still, other variables such as the researcher's way to give feedback and kinds of stuff might take the role in reducing their writing apprehension level.

\section{Writing Apprehension and Writing Achievement of the Students}

In answering the second research question, the researcher did Pearson correlation analysis. This test was done to figure out the relationship between students' writing apprehension level and their writing achievement. Since the results from previous studies are varied, the researcher would like to discover whether the present finding is negatively correlated or on the contrary, it has positive correlation; or even, it does not correlate at all. Then, if it is correlated, the researcher would like to know whether it has significant value or not.

Three times correlation analyses were done by the researcher to get more specific results; correlation analysis of the scores before the treatments, correlation analysis of the scores after the treatments, and the correlation analysis of gained scores. The results were all negative, meaning that the lower the writing apprehension level the students had, the better their writing achievement would get. Surprisingly, two out of three findings had very high correlation, meanwhile, the gained scores correlation analysis showed a moderate correlation. In addition, the significant values were all less than 0.05 , meaning that all findings were significant. To summarize, two findings indicated very high negative significant correlation and the rest presented an average negative significant correlation.

As a matter of fact, previous research has demonstrated a clear, consistent, and significant correlation between a student's level of writing apprehension and writing achievement in both first and second languages. Masny and Foxall (1992) as cited in Kim (2006) found that high achieving writers were less apprehensive; also Takahashi (2010) who concluded that writing apprehension was found to be negatively related to class achievement/proficiency for Japanese EFL students.

To sum up, the implementation of WhatsApp in online writing class is effective to reduce students' writing apprehension in the Indonesian EFL context, especially in recount text writing. Briefly, this chapter has presented the results of this research and discussed points related to the results of the research. In the following chapter, the researcher will elaborate on the conclusions of this research and present several suggestions for the other scholars and the English teachers.

\section{CONCLUSIONS AND SUGGESTIONS}

\section{Conclusions}

There is a significant difference in students' writing apprehension after treatments. It is found that the implementation of WhatsApp in online learning setting decreases students' writing apprehension level positively. Furthermore, the researcher did three times correlation analyses between writing apprehension and writing achievement to obtain more specific results. The findings show significant negative correlation which implied that, the lower the level of writing apprehension is, the higher the score of writing achievement would be. These findings are in line with numerous previous studies. 


\section{Suggestions}

There are some suggestions for English Teachers; first, in implementing online learning, it is recommended for English teachers to use WhatsApp, especially for teaching writing skill. WhatsApp is easy and free to operate, it is a famous messenger application that has been used by numerous individuals, especially in Indonesia. Second, since online learning does not have face-to-face interaction, the teachers must assure the students to have actively participated in the online classes. The last, since it applied online learning, the teachers should construct an authentic course (materials, tests, etc.) to prevent students from cheating.

There are suggestions for other researchers who would like to conduct similar research as well; first, this study was conducted at the Senior High School level. Therefore, it is suggested for further researchers to conduct at the university level instead. Conducting this kind of research in university students majoring in English will give more proper results. Second, future researchers are suggested to combine quantitative and qualitative research methodologies to consider the variables in order to better understand the nature of writing apprehension, an important factor that contributes to the writer's block and fear for the EFL learner. Third, it is better to investigate students' perceptions after the treatments to figure out how the students portray the learning activities that have been done. The last, since this study implemented online learning, future researchers may apply blended learning (the combination of online learning settings with faceto-face learning) to maximize the process of teaching-learning activities.

\section{REFERENCES}

Ali and Bin-Hady. (2019). A study of EFL students' attitudes, motivation and anxiety towards WhatsApp as a language learning tool. Arab World English Journal (AWEJ) Special Issue on CALL (5).289-298.

Al_Sawalha, Salem, M. A., Chow, and Foo, T. V. (2012). The effects of writing apprehension in English on the writing process of Jordanian EFL students at Yarmoukuniversity.International Interdisciplinary Journal of Education, 1(1), 6-14.

Alwasilah, A.C. (2004). Persfektif Pendidikan Bahasa Inggris di Indonesia :Dalam Konteks Persaingan Global. Andira: Bandung.

Aulia, V. (2018).Reducing students' pronunciation anxiety by utilizing WhatsApp group in learning English consonant sounds.ELT Worldwide, 5(2), 165-178.

Ariyanti. (2016). The teaching of EFL writing in Indonesia. Dinamika Ilmu, 16( 2), 263-277.

Challob, A. I., Bakar, N. A., and Latif, H. (2016). Collaborative blended learning writing environment: Effects on EFL students' writing apprehension and writing performance. Canadian Center of Science and Education: English Language Teaching, 9(6); 229-241.

Cheng, Y.S. (2002). Factors associated with foreign language writing anxiety. Foreign Language Annals, 35(6), 647-656.

Daly, J.A. and Miller, M.D. (1975). The empirical development of an instrument to measure writing apprehension. Research in the Teaching of English, 9(3), 242-249.

Erkan, D.Y. and Saban, A.I. (2011). Writing performance relative to writing apprehension, selfefficacy in writing, and attitudes towards writing: A correlational study in Turkish tertiary-level EFL. Asian EFL Journal,13(1), 164-192. 
Gilakjani, A. P. (2013). Factors contributing to teachers' use of computer technology in the classroom. Universal Journal of Educational Research,1(3), 262-267.

Han, T., \&Keskin, F. (2016). Using a mobile application (WhatsApp) to reduce EFL speaking anxiety. Gist Education and Learning Research Journal, 12, 29-50.

Harmer, J. (2004). How to teach writing. New York: Pearson.

Horwitz, E. K., Horwitz, M. B., and Cope, J. A. (1986). Foreign language classroom anxiety. Modern Language Journal, 70(2), 125-132.

Huwari, I.F. \&Al-Shboul, Y. (2016). Student's strategies to reduce writing apprehension (a case study on Zarqa university). Mediterranean Journal of Social Sciences, 7(3), 283-290.

Kim, K. J. (2006). Writing apprehension and writing achievement of Korean EFL college students. English Teaching, 61(1), 135-154.

Mwakapina, J.W., Mhandeni, A.S., and Nyinondi, O.S. (2016). WhatsApp mobile tool in second language learning: Opportunities, potentials and challenges in higher education settings in Tanzania. International Journal of English Language Education, 4(2), 70-90.

Pranoto, E., Suciati, \&Sunarno, W. (2014). The effectiveness of the implementation of problem based learning (PBL), blended learning (BL) models, and their integrity of learning outcomes viewed from the evaluation ability and student creativity the effectiveness of implementation of problem based Learning (PBL). Bioedukasi, 7(1), 44-50.

Rambe, P., \&Bere, A. (2013). Using mobile instant messaging to leverage learner participation and transform pedagogy at a South African University of Technology. British Journal of Educational Technology, 44(4), 544-561.

Rambe, P., \&Chipunza, C. (2013). Using mobile devices to leverage student access to collaboratively-generated resources: A case of WhatsApp instant messaging at a South African University. Paper presented at the International Conference on Advanced Information and Communication Technology for Education (ICAICTE 2013).331-337.

Richard, J.C., \&Renandya, W.A. (2002).Methodologyin language teaching: An anthology of current practice. Cambridge University.

Sanu, L. O. (2016). Narrative paragraph writing of the second semester student of state institute of Islamic studies (IAIN) Samarinda a syntactic analysis. Script Journal: Journal of Linguistic and English Teaching, 1(1), 36-45.

Sundari, H., \&Febriyanti, R. H. (2017). Writing apprehension in the writing class: Indonesian EFL learners context, 9(1), $34-44$.

Yuliana, D., Imperiani, E. D. A., \& Kurniawan, E. (2016). English writing skill analysis of first year Indonesian Tertiary Students in a University in Bandung.Jurnal Pendidikan Bahasa dan Sastra, 16(1), 43-57. 